\title{
Analysis of Operational Loading and Unloading Equipment in Sea Transportation
}

\author{
Petrus Pattiasina \\ Academy Maritime Veteran of the Republic of Indonesia (AMI Veretan) \\ Makassar, Indonesia
}

Received: August 5, 2014 Accepted: September 1, 2014 Published: September 3, 2014

doi:10.5296/csbm.v1i2.6265 URL: http://dx.doi.org/10.5296/csbm.v1i2.6265

\begin{abstract}
The background of this research is the increasing of marine transportation activities. The following of the activities is the improvement of community welfare nationwide. Accordingly the utilitation of all infrastructures related to sea transportation activities, should be improved in order to make the distribution of goods less expensine. The cost of loading and unloading by using shore crane and ship's crane are different. The problem related to loading and unloading process is the unequality of operational cost between shore crane and ship's crane. The main objective of this research is to compare cost and time performance of each of above mentioned cranes. The research focused on general cargo ship. The analysis was done by comparing of cost and time of operational of both type of cranes. The result of the study showed the shore crane is more suitable and efficient than ship's crane from cost and time point of view.
\end{abstract}

Keyword: Loading and Unloading

\section{Introduction}

Increase of sea transportation activity has a positif effect to economic growth and development, specially in the isolated area which is not reached by transportation facility. In Indonesia, there are still many areas which not reached by transportation facility for the sake of development. Therefore it is necessary to use sea transportation for the need of goods distribution and service. Sea transportation in Indonesia is a vital facility in supporting the smooth of economic growth and development in one area, when if seen from geografical condition, Indonesia as an Archipelago or Maritime Country which consist of thousand small and big island. So the role of sea transportation facility is urgent for distribution of goods and for development in all area. 


\section{Macrothink}

Sea Transportation activity in one area can not be separated from the function of port as a place of loading and unloading goods and service, and the available of supporting facility. In a port, it will be many obstacles which hamper the smooth of loading and unloading activity. Not only caused by port capacity but also by loading and unloading facility, cargo volume and human resource quality and quantity. The problem is which or what equipment used for loading and unloading, that is proper crane used for General Cargo ship which perform loading and unloading activity by package model of pallet route at Makassar Port in one trip. The aim of this discussion is to decide loading and unloading equipment which proper to use for taking goods from the ship to the quay and vice-versa, through Makassar Port to Surabaya Port, or other port by fixed route or liner system.

\section{Library Review}

\subsection{Definition of Port}

If we see definition and function of a port, it can be concluded that port is an area of economical activity enviroment. As included in Indonesia Government Regulation No. 21 Year 2010 about Port, article 1 which stated that "Port is a place consist of land and water around with certain borders as a place of governmental and economical activity, used by a place for ship mooring, berthing, embarkation and debarcation of passenger, or loading and unloading cargo, completed by facility of shipping line safety and supporting activity, and also as a place of inter-and intramode transportation movement". While, Salim (1993) give definition as follows: Port is a enviroment of work which consist of land and water completed by facilitier for mooring and berthing of ship and then cargo loading and unloading, as well as passengers embarcation-debarcation from a transportation moda to another transportation mode.

\subsection{Definition of Port Facilities}

According to Misliah ( 1995) port facility is ships which are being or have performed port operational activity. Until nowdays the ships which sail on sea transportation line, thase are ships which connected domestic ports, generally conventional ships. In the short conning time it will be operated advanced technology ships.

\subsection{Definition of Port Infrastructure}

According to Misliah ( 1995), Infrastructure is facilities at the port to support the success of port in serving ships and goods, to elevate the operation of its tasks and success in goods and passenger flow service. Therefore the port supported by :
a. Quay
b. Cargo Handling Equipments
c. Warehouse
d. Supporting Facilities 


\section{Methodology of Research}

\subsection{Method Which Used in This Research}

1) Primary data is data taken from direct interview with the respondents, the interview is about cargo loading and unloading activity, such as the time, freight of crane rental and so on, obtained when doing research at Makassar Port.

2) Secondary data is data taken from documentation which has been available in the from of numbers or report by related institution which dealing with the subject of this research, such as fee of equipments and its investation, also ship arrival flow.

3) Technique of Data Analysis. Data which have been taken, analyzed suited with the purpose of research. In the problem stating, data analysis is done by quantitative descriptive analysis with matemathics model and qualitative descriptive analysis that is description based on given theory to determine ideas operational management of loading and unloading equipment of sea transportation.

The speed of loading and discharging of ship the port (tonnage / hours). Tonnage / hours of ship at mooring is average numbers tonnage of cargo per hours per ship during the ship is at mooring buoy and calculated with the the formula as follow :

Formula $=\sum$ Shipload

\section{Sy mooringbuoShiptimeat}

Operation freight of ship at port ( $\mathrm{Rp}$ / tonnage), is freight of ship expended when the ship do loading and discharging activity, and calculated by the following formula :

Formula $=\sum$ Fixed fee at port $\mathrm{x}$ Time of loading $\&$ discharging

\section{¿Loading Cap acity/ Paylod}

Reduction fee / depresiation, is a cost analysis which calculated in bank account, because reduction freight is not expense through the treasury, and calculated by the following formula:

Formula $=$ Bdep $=\underline{B i}$

$$
n
$$

Where :

Bdep $=$ Reduction freight

$N=$ Technical age of ship

$B i=$ The price of Ship in the year of acqusition

The use of loading and unloading equipment must be considered in determining carning which dealing with is be earning for port and stevedoring company. Earning from loading and unloading equipment could be determined by using the following formula : 


\section{Macrothink}

Earnings $=\underline{\text { froundtrip loadxtimeo }}$

$$
340 \text { days } x \text { Eship }
$$

Calculation of ship crane operation freight use the following formula :

Speed of Loading and discharging $=\sum$ ship cargo

$$
\text { ¿Time of ship at mooring buoy }
$$

Operasional freight at port $=\sum$ fixed fee a port $x$ time of loading $\&$ discharnging

\section{$\sum$ Load capacity/payroll}

Calculation of shore crane operational freight, use the following formula: Fee at crane rental $x$ time of loading and discharging

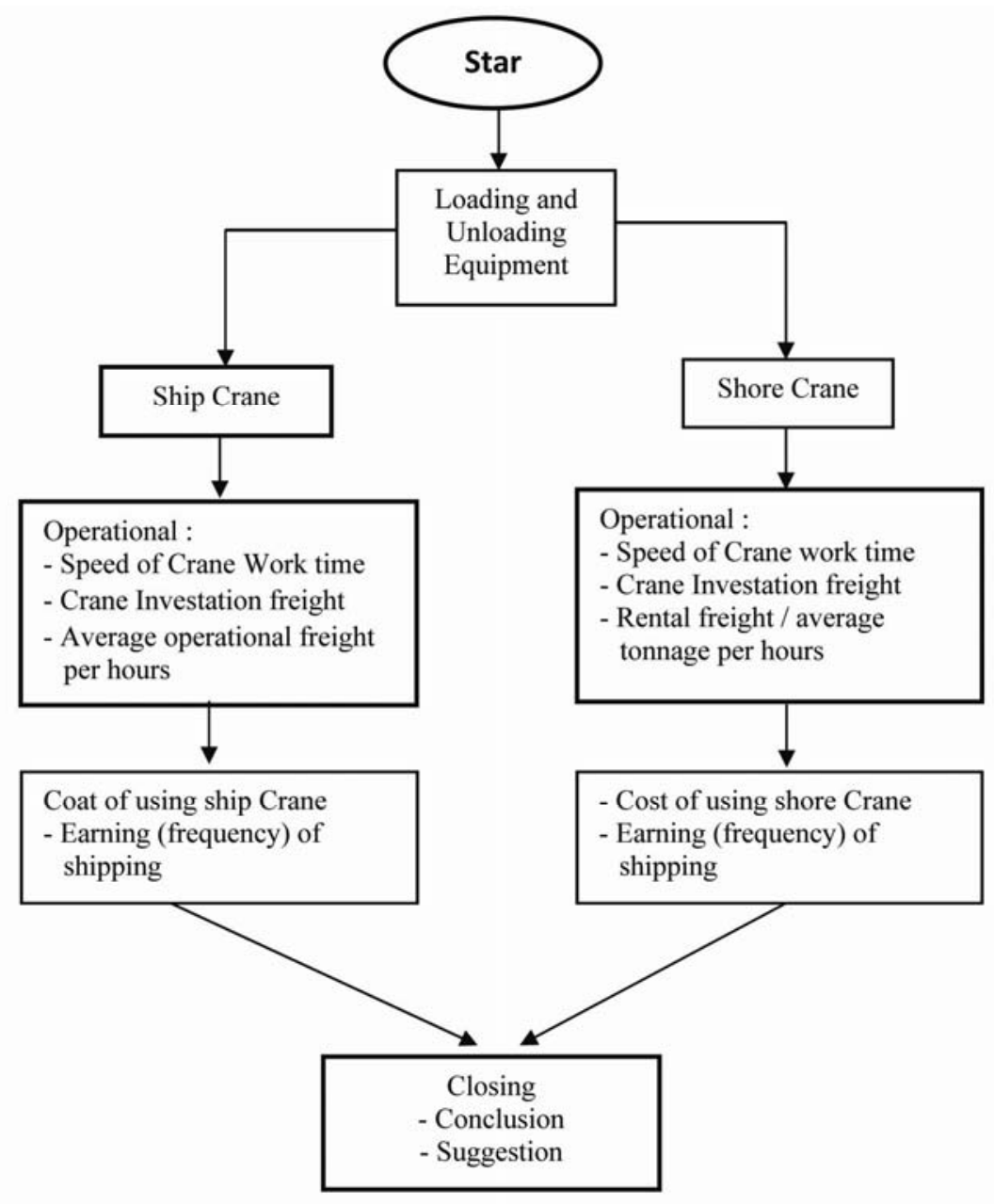

Figure 1. Flow diagram 


\section{Findings and Discussion}

From observation, there are 35 times for 4 ship ( MV. Theresia II, MV. Super MV. Loka, MV. Tanto Permai II ). It obtained average work hours of crane.

Based on the result obtained, work haurs of ship crane to unloading and loading, is 10,23 minutes and 9,16 minutes. With assumption that every goods unloading and loaded is about 3,88 tons and 4,05 tons/hour, so could be known speed of crane work to unloading is 22,76 tons/hour, and speed of crane to load is about 26,53 tons/hour.

\subsection{Calculation of Average Point of Work Crane Speed Which Use Shore Crane}

From the observation about using shore crane for 35 times to the ship MV. Theresia II. The time of shore crane work is 4,77 minutes and 4,40 minutes. With assumption that each goods which unloading and loaded is 5 tons and 6,25 tons/hour, so it can be concluded that speed of crane work hour to unloading is $\mathbf{6 2 , 9}$ tons/hour and speed at crane work hour to load is $\mathbf{5 2 , 8}$ tons/hour.

\subsection{Crane Work Time}

MV. Theresia II has payload 3600 tons. Be couse, This research discuss about calculation of crane work hour, so it must be viewed on using of ship crane equipment and shore crane, it means that this research only limited to one cargo hold. MV Theresia has two bulkheads with capacity about :

Table 1. Structure and calculation of the cost of KM. Theresia II 2699 GRT

\begin{tabular}{llllll}
\hline \multirow{2}{*}{ No } & \multirow{2}{*}{ Uraian } & \multirow{2}{*}{ Satuan } & $\begin{array}{l}\text { Satuan } \\
\text { Kalkulasi }\end{array}$ & Crane Kapal & Crane darat \\
\cline { 5 - 6 } & & & -1 & 3.600 & 3600 \\
2 & Kapasitas muat/payload & Ton & -2 & $140.699,-$ & $190.079,00$ \\
3 & Biaya di pelabuhan & Rp/jam & -2 & $24.645,-$ & $57,85,-$ \\
4 & Wecepatan B/M & Ton/jam & -3 & $292,15,-$ & $124,46,-$ \\
5 & Waktu efektif B/M & Jam & $2(1) /(3)$ & $29,-$ & \\
& (termasuk non efektif) & & & & $497,84,-$ \\
6 & Biaya kapal di pelabuhan & Rp/jam & (2) $(5) /(1)$ & $45,670,-$ & $26,286,-$ \\
\hline
\end{tabular}

Average cargo capacity $=\underline{\text { Payload }}$

$$
=1800 \text { tons }
$$

Speed at crane work hour, as follows :

1). By using ship crane loading and unloading equipment :

Formula $=\sum$ ship load

¿time of ship at mooring buoy 


\section{Macrothink Institute ${ }^{\mathrm{TM}}$}

Time of unloading $=\underline{1.800 \text { ton }}$

\section{2,76 ton /hour}

Time of loading $=\underline{1.800 \text { ton }}$

$$
=67,85 \text { hours }
$$

\section{6,53 ton /hour}

2). By using shore crane loading and unloading equipment :

Time of unloadingr $=\underline{1.800 \text { ton }}$ $=28,62$ hours

\section{2,9 ton /hour}

Time of loading $=\underline{1.800 \text { ton }}$ $=34,09$ hours

\section{2,8 ton /hour}

From the calculation above, we know that unloading time by using shore crane is less that is 28,62 hours if it compared with using ship crane that is 79,09 hours, the difference about 50,47 hours, with percentage $0,50 \%$. White time of loading by using shore crane is 34,09 hours and by using ship crane is 67,85 hours, the difference is about 33,76 hours with percentage $0,34 \%$.

\subsection{Calculation at Ship Operational Cost during Loading and Unloading Activity at Port}

From the calculation above we know taht ship operational cost at the port that must be spent by using shore crane is lower than using ship crane the difference is about Rp. 26.978.151 minus Rp. 21.954.049,- is Rp. 5.022.102,-/hour or whit percentage 5,02\%. So, it is benefit to use shore crane than ship crane. This is caused by time of loading and unloading by ship crane is slower than shore crane, as result of cargo stowage and arrangement on deck which is not sistematic as the stowage plan, and also the skill of worker, as well as non-technical factor when loading and unloading activity going on, so it influence all components of ship operational cost / hour during at port.

Tabel 2. Biaya Opersional Kapal selama di Pelabuhan

\begin{tabular}{|c|c|c|c|}
\hline \multirow{2}{*}{$\begin{array}{l}\text { Komponen biaya kapal di } \\
\text { pelabuhan }\end{array}$} & \multicolumn{3}{|l|}{ Alat angkat } \\
\hline & $\begin{array}{l}\text { Ship Crane } \\
\text { (Rp/jam) }\end{array}$ & $\begin{array}{l}\text { Shore Crane } \\
(\mathrm{Rp} / \mathrm{jam})\end{array}$ & $\begin{array}{l}\text { Selisih } \\
\text { (Rp/jam) }\end{array}$ \\
\hline Depresisasi & 119.882 & 152.558 & 32.676 \\
\hline $\mathrm{ABK}$ & 8.825 .456 & 5.012 .395 & 3.913 .061 \\
\hline RMS & 6.858 .222 & 3.895 .110 & 2.963 .112 \\
\hline Asuransi & 947.555 & 538.101 & 409.394 \\
\hline Manajemen & 910.510 & 521,666 & 396.844 \\
\hline BBM & 6.754 .325 & 1.826 .715 & 4.927 .610 \\
\hline Minyak Pelumas & 1.413 .243 & 369.218 & 1.044 .025 \\
\hline Uang tambat & 1.110 .350 & 2.013 .118 & 907.032 \\
\hline Sewa crane darat & - & 9.416 .500 & 9.406 .500 \\
\hline Jumlah & 26.975 .151 & 21.994 .049 & 5.922 .092 \\
\hline
\end{tabular}




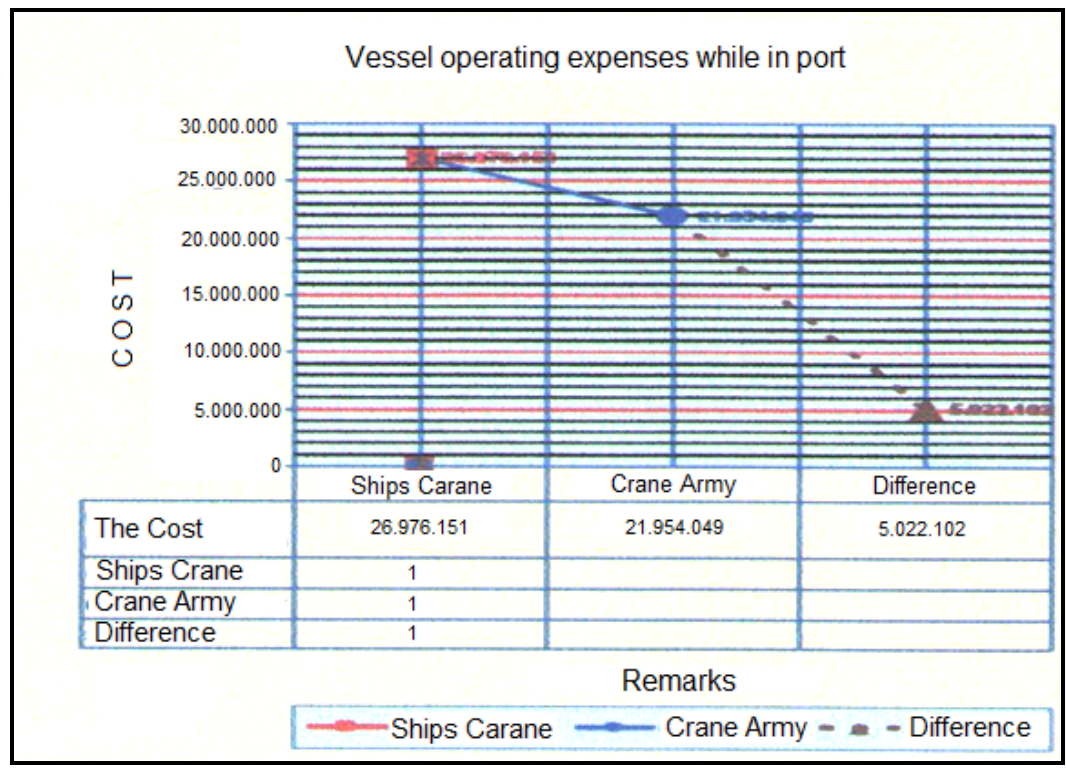

Figure 2. Vessel operating expenses for port

Based on calculation in the above, we know that the cost of ship which use crane ship is about 45.672/ton, White, the cost of ship which use shore crane is about Rp. 26.286/ton.

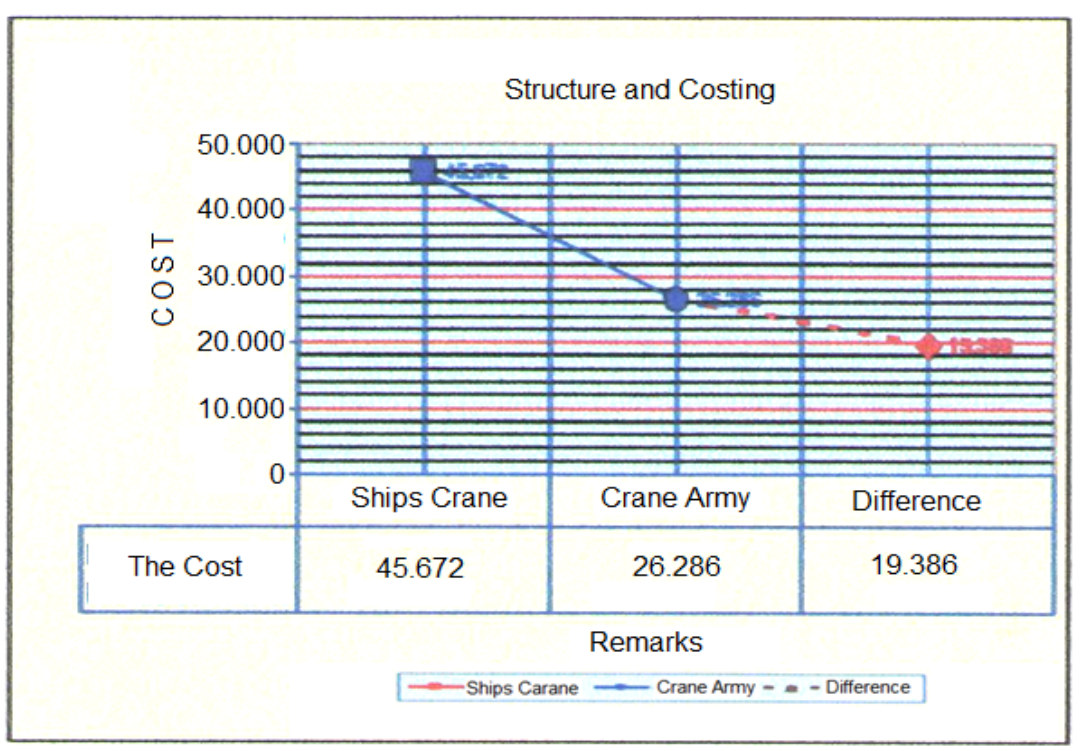

Figure 3. Structure and costing per trip 


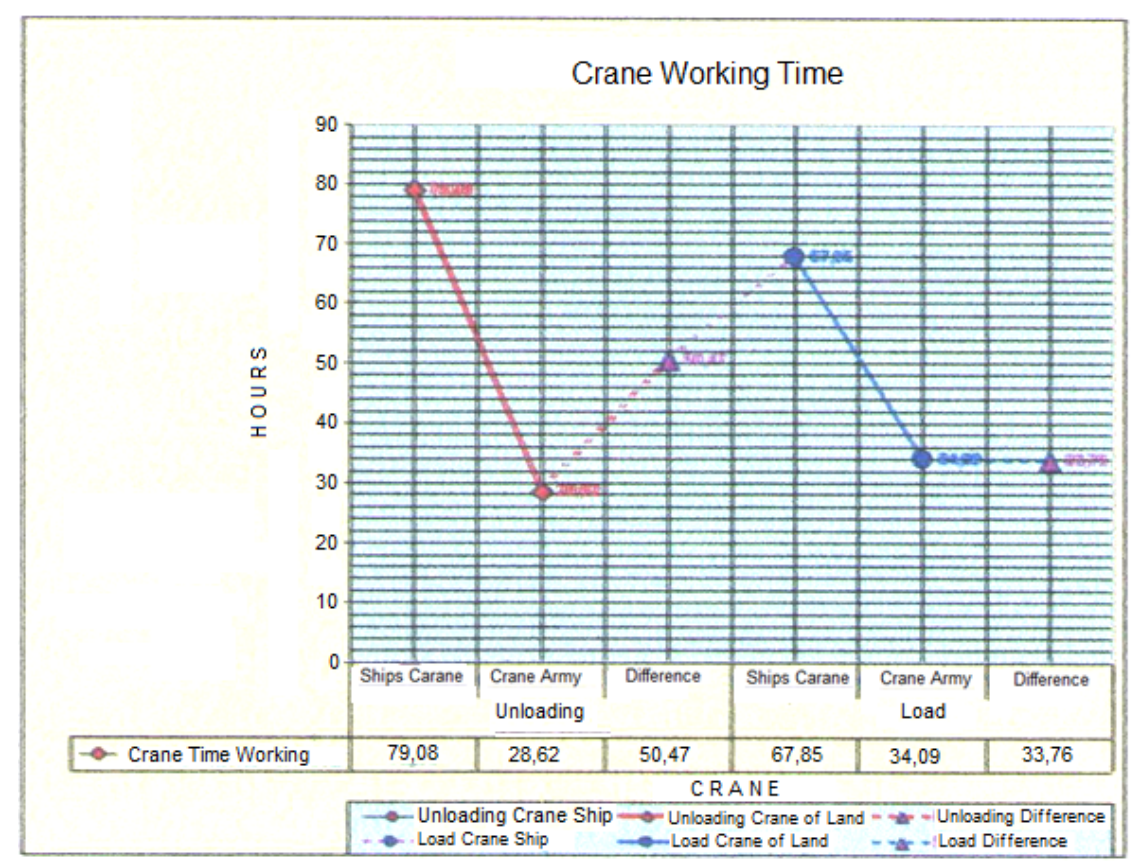

Figure 4. Working time crane

\subsection{Determination of Loading and Unloading Equipment}

From the result of research and calculation that loading and unloading equipment which suitable to be used by general cargo ship in loading and unloading activity by pallet packaging model at port in Makassar or other port with fixed routes is Shore Crane, viewed from operational cost aspect and also time, is very cheap and more beneficial.

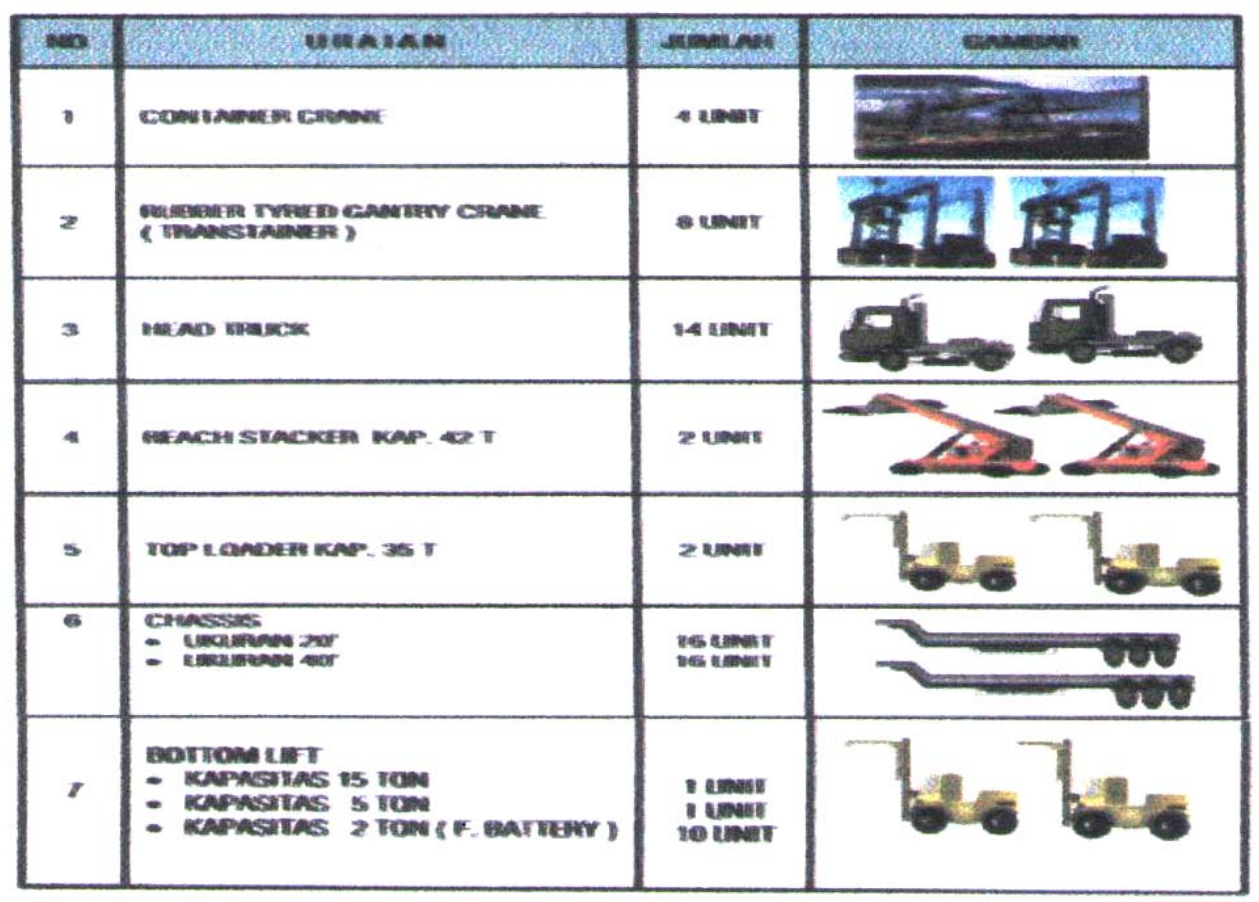

Figure 5. Equipment $\mathrm{B} / \mathrm{M}$ in the port of Makassar 


\section{Conclusion}

Based on the analysis at financial comparation between using ship crane and shore crane, it can be concluded that :

1) Ship operational cost during at port if using ship crane is Rp. 29.120.517/trip, white if using shore crane, the operational cost is about Rp. 22.176.038/trip. And the time during at port is 166,11 hours. White the time for shore crane at port is 98,62 hours.

2) Refer to the problem the purpose of this research, the result of analysis and calculation about using shore crane is better than ship crane, viewed from speed and operational cost of loading and unloading activity during at port.

\section{Suggestion}

From the conclusion above, so it is suggested as follows :

1) Related Institution at port environment, this is as a basic to determine a policy for increasing and placing equipment that is shore crane suitable with the port condition, whether at the main port, or at class I, class II or other port, especially the port wich transitted regularly or liner system, such as Makassar Port, Surabaya

2) Port, there fone they are able to give carnings for the local government.

3) By the growth of transportation technology, it is hoped to the owner to consider about placing crane on boord.

4) It is suggested also to pay attention to the port which do not have crane, the ship which does not have a ship crane can not do loading and unloading activity if at port called on not had the shore crane.

\section{References}

Biro Hukum \& Organisasi Dephub. (2008). Undang-Undang No. 17 Tahun 2008, tentang Pelayaran, Jakarta.

Biro Hukum \& Organisasi Dephub. (2009). Peraturan Pemerintah No. 61 Tahun 2009, tentang Kepelabuhanan, Jakarta.

Biro Hukum \& Organisasi Dephub. (2010a). Peraturan Pemerintah No. 5 Tahun 2010, tentang Kenavigasian, Jakarta.

Biro Hukum \& Organisasi Dephub. (2010b). Peraturan Pemerintah No. 20 Tahun 2010, tentang Angkutan di Perairan, Jakarta.

Biro Hukum \& Organisasi Dephub. (2010c). Peraturan Pemerintah No. 21 Tahun 2010, tentang Perlindungan Lingkungan Maritim, Jakarta.

Hadiman, H. (2009). Undang-Undang No. 22 Tahun 2009, tentang Lalu Lintas dan Angkutan Jalan, Penerbit BKS Sosial Usaha Pembinaan Warga Tama, Jakarta. 


\section{Macrothink}

Hoesien, R., \& Manuputty, D. (2009). Kamus Pelayaran, Penerbit Citra Harta Prima, Cetakan Pertama, Jakarta.

Kosasih, E., \& Soewedo, H. (2007). Manajemen Keuangan \& Akuntansi Perusahaan Pelayaran, Penerbit PT. Raja Grafindo Persada, Jakarta.

Kramadibrata, S. (2002). Perencanaan Pelabuhan, Penerbit ITB, Bandung.

Lasse. (2012). Manajemen Muatan, Penerbit Nika, Jakarta.

Morlok, E. K. (1984). Pengantar Teknik dan Perencanaan Transportasi, PN. Erlangga, Jakarta.

Nasution, H. M. N. (1996). Manajemen Transportasi, Penerbit Ghalia Indonesia, Jakarta.

Purba, R. (1997). Angkutan Muatan Laut, Jilid I, Penerbit PT. Rineka Cipta, Jakarta.

Sudjatmiko, F. D. C. (1995). Pokok-Pokok Pelayaran Niaga, PT. Toko Gunung Agung, Jakarta.

Suyono, R. P. (2001). Shipping (Pengangkutan Intermodal Ekspor Impor Melalui Laut), Penerbit PPM, Jakarta Tamin, Ofyar Z 2000. Perencaraan dan Pemodelan Transportasi, Penerbit ITB, Bandung.

Tamin, O. Z. (2000). Perencaraan dan Pemodelan Transportasi, Penerbit ITB, Bandung.

Zulfiar, S. (2013). Ekonomi Transportasi, PN. Universitas Indonesia, Jakarta.

\section{Copyright Disclaimer}

Copyright for this article is retained by the author(s), with first publication rights granted to the journal.

This is an open-access article distributed under the terms and conditions of the Creative Commons Attribution license (http://creativecommons.org/licenses/by/3.0/). 